GREEN OPEN ACCESS* VERSION

\title{
Conserving wild Arabica coffee: emerging threats and opportunities
}

Raf Aerts, Lore Geeraert, Gezahegn Berecha, Kitessa Hundera, Bart Muys, Hanne De Kort,

Olivier Honnay

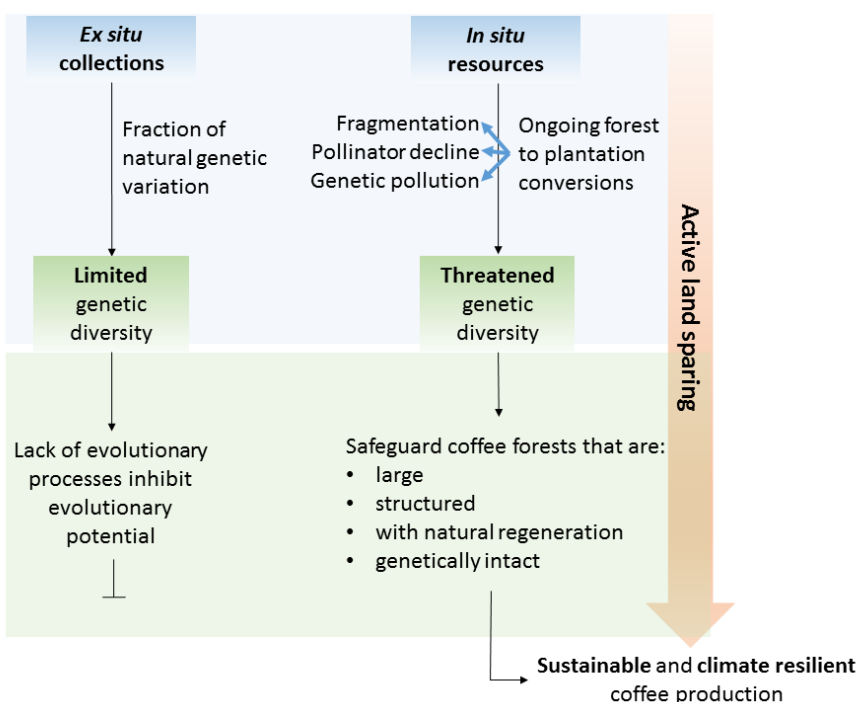

11 *Elsevier authorized the authors to post this revised personal version of the text of the final journal article on the author's institutional server, incorporating the complete citation and with

13 a link to the Digital Object Identifier (DOI) of the article.

Creative Commons Attribution-Noncommercial-Share Alike 2.0 Belgium License 
Conserving wild Arabica coffee: emerging threats and opportunities

\section{Author names and affiliations}

$25 \operatorname{Raf}_{\text {Aerts }^{\mathrm{a}}{ }^{\mathrm{a}}{ }_{*}{ }^{1}, \text { Lore Geeraert }^{\mathrm{a}}, \text { Gezahegn Berecha }^{\mathrm{c}}, \text { Kitessa Hundera }^{\mathrm{d}} \text {, Bart Muys }}{ }^{\mathrm{b}}$, Hanne De Kort $^{\mathrm{a}, \mathrm{e}}$ \& Olivier Honnay ${ }^{\mathrm{a}}$

${ }^{a}$ Plant Conservation and Population Biology, University of Leuven, Kasteelpark Arenberg 312435, BE-3001 Leuven, Belgium.

29 raf.aerts@kuleuven.be, lore.geeraert@kuleuven.be, olivier.honnay@kuleuven.be

313001 Leuven, Belgium.

32 bart.muys@kuleuven.be

$33{ }^{\mathrm{c}}$ Department of Horticulture and Plant Science, Jimma University, P.O. Box 378, Jimma, 34 Ethiopia.

35 gberecha@yahoo.com

$36{ }^{\mathrm{d}}$ Department of Biology, Jimma University, P.O. Box 378, Jimma, Ethiopia.

37 kitessah2@yahoo.com

38 e Station d'Ecologie Théorique et Expérimentale du CNRS, Centre National de la Recherche

39 Scientifique, 2 Route du CNRS, FR-09200 Moulis, France

40 hanne.dekort@sete.cnrs.fr 
41 *Corresponding author: raf.aerts@kuleuven.be

421 Present address: Health and Environment, Scientific Institute of Public Health, Rue Juliette 43 Wytsmanstraat 14, BE-1050 Brussels, Belgium.

44 
Climate change and emerging pests and diseases are posing important challenges to global crop productivity, including that of Arabica coffee. The genetic basis of commercially used Arabica coffee cultivars is extremely narrow, and it is uncertain how much genetic diversity is present in ex situ collections. Conserving the wild Arabica coffee gene pool and its evolutionary potential present in the montane forests of SW Ethiopia is thus critically important for maintaining coffee yield and yield stability worldwide. Globally, coffee agroforestry helps to conserve forest cover and forest biodiversity that cannot persist in open agricultural landscapes, but the conservation of the wild Arabica coffee gene pool requires other priorities than those that are usually set for conserving forest biodiversity in mixed tropical landscapes. We show how forest loss and degradation, coffee management, in particular production intensification, and the introduction of cultivars, are threatening the genetic integrity of these wild populations. We propose an active

57 land sparing approach based on strict land use zoning to conserve the genetic resources and the in situ evolutionary potential of Arabica coffee and discuss the major challenges including the development of access and benefit sharing mechanisms for ensuring long-term support to

60 conservation.

61

\section{Keywords}

63 agricultural intensification; agroforest; Coffea arabica; crop wild relative; Ethiopia; genetic resources 


\section{Introduction}

Coffee is grown in more than 70 countries across the tropics and the annual export value of coffee exceeds US\$24 billion (FAO, 2015). The market demand for coffee is still rising, but climate change and emerging pest and diseases are posing important challenges to global coffee productivity (Läderach et al., 2010; Bunn et al., 2015). Outbreaks of coffee rust, coffee berry borer beetles and root nematodes have already reduced coffee yield and degraded coffee quality in coffee plantations around the world (Jaramillo et al., 2011; Avelino et al., 2015). The high susceptibility of commercial plantations to pests and diseases that seem to accompany global change and rising temperatures (Ghini et al., 2011), and the overall expected limited resilience of monocultures against environmental change in general (Lin, 2011), can be largely attributed to the very narrow genetic basis of the commercially used coffee cultivars (Anthony et al., 2001). These plants have a very limited potential to adapt, a feature shared with many other important crops (Fernie et al., 2006) including Cavendish banana, soybean, maize and cocoa. For Arabica coffee (Coffea arabica L.), accounting for $60 \%$ of all coffee produced globally and of higher organoleptic quality than the other commercially used coffee species Coffea canephora or 'Robusta' coffee, the narrow genetic basis is mainly related to major genetic bottlenecks during global dissemination of Arabica coffee. The plants that were originally introduced in Latin America and the Caribbean all descended from a few individuals that grew in Java, grown from seeds collected in Yemen, which in turn were the fruits of a few mother plants that most likely had their roots in the southwestern highlands of Ethiopia (Anthony et al., 2001). Given the very low genetic diversity of Arabica coffee cultivated worldwide, the extant wild gene pool of $C$. arabica in SW Ethiopia may prove to be essential to future-proof the global coffee economy and 
to secure the livelihood of millions of households that depend on Arabica coffee production or trade.

\section{Wild Arabica coffee in Ethiopia}

Wild Coffea arabica occurs as an understory shrub and has its center of diversity in the moist evergreen 'coffee forests' of southwestern Ethiopia (Anthony et al., 2001). Both wild populations and locally cultivated varieties (landraces) are still characterized by wide genotypic and phenotypic variability (Labouisse et al., 2008) and studies based on genotypic fingerprinting have provided evidence that Ethiopian wild provenances are genetically distinct from the most widely commercially used varieties Typica, Bourbon and Caturra (Anthony et al., 2001; Chaparro et al., 2004; Silvestrini et al., 2007; Tesfaye et al., 2014). The genes conserved in the Ethiopian wild gene pool are responsible for a number of desirable traits such as low caffeine content (Silvarolla et al., 2004), higher quality specialty grade (Berecha et al., 2014a) or resistance to root nematodes and coffee berry disease (Boisseau et al., 2009). These genes and genes related to other traits of wild coffee are essentially the genes needed to adapt coffee to changing climate and market demands. In these naturally regenerating populations, allele frequencies and gene combinations constantly change in a process of adaptation to external drivers, including climate change and disease pressure. Such evolutionary processes are lacking in ex situ collections of coffee (Schoen and Brown, 2001), including the collection of CATIE (Centro Agronómico Tropical de Investigación y Enseñanza) which includes c. 10,000 coffee trees, representing 1850 accessions, of which c. 600 accessions were collected in the Ethiopian center of Arabica coffee diversity (Anthony et al., 2007). In ex situ collections, coffee shrubs are kept outside their natural habitat under homogeneous environmental conditions and low disease 
111 pressure. Together with the typically clonal regeneration of the cultivars, this prevents adaptation

112 of coffee collections to changing environments (Anthony et al., 2007). A dynamic, in situ

113 conservation approach allowing natural regeneration and evolution is therefore the best way for

114 conserving a coffee gene pool that is free to adapt to climate change and emerging pests and

115 diseases, and that can be used to harness coffee cultivation worldwide in the face of such

116 challenges (Sgrò et al., 2011; Sarrazin et al., 2016).

\section{Imminent threats to wild Arabica coffee}

119 Globally, coffee agroforestry helps to conserve forest cover and forest biodiversity that cannot persist in open agricultural landscapes (Tscharntke et al., 2011). Also in Ethiopia, extensive coffee production systems including semi-forest coffee and homegarden coffee have been demonstrated to support the conservation of forest cover (Aerts et al., 2011; Hylander et al., 2013) and associated components of forest biodiversity (Gove et al., 2008; Hylander and Nemomissa, 2008; Tadesse et al., 2014a; Buechley et al. 2015) in landscapes that in the absence of coffee would be entirely converted to open crop- and grazing land (Tadesse et al., 2014b). Nevertheless, the conservation of the wild Arabica coffee gene pool requires other priorities than those that are usually set for conserving forest biodiversity in mixed tropical landscapes, such as the conservation of small forest patches, isolated trees and hedgerows (Muñoz et al., 2013). Like cultivated Arabica coffee elsewhere, also wild Arabica coffee is susceptible to climate change, and a bioclimatic model for $C$. arabica predicts a 38 to $90 \%$ reduction of the suitable area within

131 its native range by 2080 (Davis et al., 2012). However, multiple direct threats to the in situ conservation are currently more imminent. First, ongoing loss and fragmentation of natural

133 coffee forests (Tadesse et al., 2014a;b) are directly threatening wild coffee populations and the 
genetic diversity present. In the core area of coffee diversity, we continue to observe the fast replacement of natural coffee forest harboring wild coffee populations by intensively managed coffee plantations (Fig. 1). Decreased coffee population size and increased spatial isolation may cause inbreeding at the expense of local fitness and associated disease resistance and productivity (Jump and Peñuelas, 2006). In addition, increased genetic drift in small and fragmented populations compromises the ability to cope with changing environmental pressures due to the loss of (cryptic) beneficial genetic variation (Honnay and Jacquemyn, 2007). Second, coffee forest management intensification leads to degradation and simplification of forest structure and plant communities (Figure 1B; Senbeta and Denich, 2006; Schmitt et al., 2009; Hundera et al., 2013). The meticulous harvesting of coffee berries, transplanting of coffee seedlings and frequent slashing of the understory vegetation disturb the natural regeneration process and the age structure of the coffee populations (and other tree species) (Berecha et al. 2014b; Hundera et al. 2015) and inhibit the process of natural selection in response to environmental change (Jump et al., 2009). The biotic and structural homogenization also results in a forest hosting less diverse pollinator communities (Samnegård et al., 2014; Berecha et al., 2015). This has been linked to decreased pollen dispersal and reduced outcrossing in wild Arabica coffee populations (Berecha et al., 2014b), likely negatively affecting extant genetic diversity through inbreeding. Third, the widespread introduction of locally improved cultivars resistant to coffee berry disease into natural forests since the 1970s is threatening the genetic integrity of the remaining wild coffee populations, which already show signs of admixture with these cultivars (Aerts et al., 2013). All these threats can strongly interfere with the evolutionary trajectories underlying genetic diversity and adaptive potential. Especially in fragmented and homogenized forest landscapes, where gene flow and hence the exchange of (adaptive) alleles is 
157 hampered, small population sizes can quickly result in depleted adaptive genetic diversity

158 (Bijlsma and Loeschcke, 2012). To conserve the genetic diversity required for long term

159 adaptive responses, management of the forests and the coffee populations therein should aim at

160 supporting the evolutionary processes governing genetic diversity (Sgrò et al., 2011). Thus, the

161 most important challenge involves the conservation of adequate effective population sizes and

162 gene flow dynamics in the face of ongoing forest loss and degradation (Bacles and Jump, 2011).

\section{Conservation approaches for wild Arabica coffee}

165 Given the multiple challenges related to safeguarding the evolutionary processes and the 166 adaptive potential of the wild coffee gene pool, the establishment of strict wild coffee forest

167 reserves, free from active coffee farming, is urgently needed (Fig. 2). Not to compromise the 168 interests and livelihoods of the local coffee farmers and the coffee production goals set by the 169 government as part of its poverty and hunger reduction strategy, this would basically require the 170 combination of land sparing and land sharing approaches (Phalan et al., 2011) where (i) the management in the most strongly degraded coffee forests is optimized aiming at increasing coffee yield; (ii) the management in less degraded coffee forests is optimized for biodiversity conservation and the provisioning of ecosystem services, and (iii) large tracts of natural coffee forests are not taken into production to conserve wild coffee populations. Given the currently observed fast conversion of natural forest into plantation-like coffee forest (Fig. 1), the conservation of the last remaining natural forests is imperative and providing detailed actual maps of their distribution as a first step is an absolute priority.

To avoid that local yield increase and profit encourage agricultural expansion into protected areas rather than the opposite, Phalan et al. (2016) have recently proposed a range of active land- 
sparing mechanisms that may be successfully applied to the Ethiopian wild coffee case. Strict land use zoning in combination with directed yield increasing measures is needed to successfully and permanently separate coffee production areas from coffee forest reserves. Production could be boosted, for example, through technical advice on forest, soil and disease management, and through improvement of the roads and other infrastructure in the coffee production chain. Standards and certification schemes rewarding groups of farmers with additional benefits in terms of access to production resources, to technical advice to increase coffee production and perhaps to price premiums, when conserving the strict coffee forest reserves, are likely to increase the success of such a land sparing approach. Monitoring, in particular by use of remote sensing, may be helpful to demonstrate success of the land use zoning and to identify problems so that these can be addressed early if they emerge. The designation of Yayu, Sheka and Kaffa, three coffee forests in the southwest of Ethiopia, as UNESCO biosphere reserves, is certainly an important step forward to the implementation of such an active land sparing approach in Ethiopia. The cores of these forests are proposed to be placed under land sparing management, while land sharing is practiced in the forest edges and in the other parts of the landscape (which covers more than 1 million hectares over the three reserves, see online interactive map).

An important hurdle for the sustainable exploitation of the wild coffee gene pool is the danger that these genetic resources are not used to the benefit of the Ethiopian people, in particular the Ethiopian farmers and government bodies who face the costs and burden of wild coffee gene pool conservation. The UN Convention on Biological Diversity (CBD) and Nagoya Protocol provide opportunities to develop specialized access and benefit sharing (ABS) instruments. Given the global importance of the coffee industry, a specialized ABS scheme for Arabica coffee could generate substantial funds for long-term support to the conservation of coffee genetic 
203 resources in return for fair access to the genetic resource (Richerzhagen and Virchow, 2007).

204 Together with funds derived from coffee certification schemes (Wiersum et al., 2012; Takahashi

205 and Todo, 2014) or policy mechanisms such as REDD+ (as in Yayu forest, see e.g. Phalan et al.

206 2013), this fund could become instrumental in supporting local forest managers and coffee

207 smallholder farmers to implement a combination of land sparing (reserve) and land sharing

208 (biodiversity-friendly) conservation strategies (Fischer et al., 2008) and to conserve the unique

209 biodiversity of Ethiopia's last remaining coffee forests.

211 Acknowledgments

212 The authors gratefully acknowledge the comments of Kristoffer Hylander that helped to broaden 213 the perspective of this Opinion Paper.

\section{$215 \quad$ Funding}

216 This work was supported by the University Development Cooperation of the Flemish

217 Interuniversity Council (VLIR-UOS) [research grants to LG, GB and KH]; and the Research

218 Foundation - Flanders (FWO) [research grant to RA].

\section{References}

Aerts, R., Hundera, K., Berecha, G., Gijbels, P., Baeten, M., Van Mechelen, M., Hermy, M., Muys, B., Honnay, O., 2011. Semi-forest coffee cultivation and the conservation of Ethiopian Afromontane rainforest fragments. For. Ecol. Manag. 261, 1034-1041, http://dx.doi.org/10.1016/j.foreco.2010.12.025 
Aerts, R., Berecha, G., Gijbels, P., Hundera, K., Van Glabeke, S., Vandepitte, K., Muys, B., Roldán-Ruiz, I., Honnay, O., 2013. Genetic variation and risks of introgression in the wild Coffea arabica gene pool in southwestern Ethiopian montane rainforests. Evol. Applic. 6, 243-252, http://dx.doi.org/10.1111/j.1752-4571.2012.00285.x

Anthony, F., Bertrand, B., Quiros, O., Wilches, A., Lashermes, P., Berthaud, J., Charrier, A., 2001. Genetic diversity of wild coffee (Coffea arabica L.) using molecular markers. Euphytica 118, 53-65, http://dx.doi.org/10.1023/A:1004013815166

Anthony, F., Astorga, C., Avendaño, J., Dulloo, E., 2007. III. Conservation of coffee genetic resources in the CATIE field genebank. In: Engelmann, F., Dulloo, M.E., Astorga, C., Dussert, S., Anthony, F. (Eds.), Conserving coffee genetic resources. Complementary strategies for ex situ conservation of coffee (Coffea arabica L.) genetic resouces. A case study in CATIE, Costa Rica.Tropical Reviews in Agricultural Biodiversity. Bioversity International, CATIE and IRD, pp. 23-34.

Avelino, J., Cristancho, M., Geogiou, S., et al., 2015. The coffee rust crises in Colombia and Central America (2008-2013): impacts, plausible causes and proposed solutions. Food Security 7, 303-321, http://dx.doi.org/10.1007/s12571-015-0446-9

Bacles, C.F.E., Jump, A.S., 2011. Taking a tree's perspective on forest fragmentation genetics Trends Plant Sci. 16, 13-18, http://dx.doi.org/10.1016/j.tplants.2010.10.002

Berecha, G., Aerts, R., Vandepitte, K., Roldán-Ruiz, I., Honnay, O., 2014a. Coffee cup quality deteriorates with increasing management intensity in Ethiopian Afromontane forests. In: Berecha, G. Genetic diversity, pollination ecology, and organoleptic characteristics of Coffea arabica L. in Ethiopian moist forests of different management intensity $(\mathrm{PhD}$ dissertation). Leuven, Belgium: University of Leuven, pp. 114-132. 
Berecha, G., Aerts, R., Vandepitte, K., Van Glabeke, S., Muys, B., Roldán-Ruiz, I., Honnay, O., 2014b. Effects of forest management on mating patterns, pollen flow and intergenerational transfer of genetic diversity in wild Arabica coffee (Coffea arabica L.) from Afromontane rainforests. Biol. J. Linn. Soc. 112, 76-88, http://dx.doi.org/10.1111/bij.12274

Berecha, G., Aerts, R., Muys, B., Honnay, O., 2015. Fragmentation and management of Ethiopian moist evergreen forest drive compositional shifts of insect communities visiting wild Arabica coffee flowers. Environ. Manag. 55, 373-382, http://dx.doi.org/10.1007/s00267-014-0393-9

Bijlsma, R., Loeschcke, V., 2011. Genetic erosion impedes adaptive responses to stressful environments. Evol. Applic. 5, 117-129, http://dx.doi.org/10.1111/j.17524571.2011.00214.x

Boisseau, M., Aribi, J., de Sousa, F.R., Carneiro, R.M.D.G., Anthony, F., 2009. Resistance to Meloidogyne paranaensis in wild Coffea arabica. Trop. Plant Pathol. 34, 38-41, http://dx.doi.org/10.1590/S1982-56762009000100006

Buechley, E.R., Sekercioglu, C.H., Atickem, A., Gebremichael, G., Ndungu, J.K., Mahamued, B.A., Beyene, T., Mekonnen, T., Lens, L., 2015. Importance of Ethiopian shade coffee farms for forest bird conservation. Biol. Cons. 188, 50-60, http://dx.doi.org/10.1016/j.biocon.2015.01.011

Bunn, C., Läderach, P., Ovalle-Rivera, O., Kirschke, D., 2015. A bitter cup: climate change profile of global production of Arabica and Robusta coffee. Clim. Change 129, 89-101, http://dx.doi.org/10.1007/s10584-014-1306-x 
Chaparro, A.P., Cristancho, M.A., Cortina, H.A., Gaitán, A.L., 2004. Genetic variability of Coffea arabica L. accessions from Ethiopia evaluated with RAPDs. Genet. Res. Crop. Evol. 51, 291-297, http://dx.doi.org/10.1023/B:GRES.0000024014.04471.9a

Davis, A.P., Gole, T.W., Baena, S. Moat, J., 2012. The impact of climate change on indigenous Arabica coffee Coffea arabica: predicting future trends and identifying priorities. PLoS ONE 7: e47981, http://dx.doi.org/10.1371/journal.pone.0047981

FAO, 2015. Statistical Pocketbook Coffee 2015. Food and Agriculture Organization of the United Nations, Rome.

Fernie, A.R., Tadmor, Y., Zamir, D., 2006. Natural genetic variation for improving crop quality. Current Opinion Plant Biol. 9, 196-202, http://dx.doi.org/10.1016/j.pbi.2006.01.010

Fischer, J., Brosi, B., Daily, G.C., Ehrlich, P.R., Goldman, R., Goldstein, J., Lindenmayer, D.B., Manning, A.D., Mooney, H.A., Pejchar, L., Ranganathan, J., Tallis, H., 2008. Should agricultural policies encourage land sparing of wildlife-friendly farming? Frontiers Ecol. Environ. 6, 380-385, http://dx.doi.org/10.1890/070019

Ghini, R., Bettiol, W., Hamada, E., 2011. Diseases in tropical and plantation crops as affected by climate changes: current knowledge and perspectives. Plant Pathol. 60, 122-132, http://dx.doi.org/10.1111/j.1365-3059.2010.02403.x

Gove, A.D., Hylander, K., Nemomissa, S., Shimelis, A., 2008. Ethiopian coffee cultivation implications for bird conservation and environmental certification. Cons. Lett. 1, 208-216, http://dx.doi.org/10.1111/j.1755-263X.2008.00033.x 
Honnay, O. Jacquemyn, H., 2007. Susceptibility of common and rare plant species to the genetic consequences of habitat fragmentation. Cons. Biol. 21, 823-831, http://dx.doi.org/10.1111/j.1523-1739.2006.00646.x

Hundera, K., Aerts, R., Fontaine, A., Van Mechelen, M., Gijbels, P., Honnay, O., Muys, B., 2013. Effects of coffee management intensity on composition, structure, and regeneration status of Ethiopian moist evergreen Afromontane forests. Environ. Manag. 51, 801-809, http://dx.doi.org/10.1007/s00267-012-9976-5

Hundera, K., Honnay, O., Aerts, R., Muys, B., 2015. The potential of small exclosures in assisting regeneration of coffee shade trees in South-Western Ethiopian coffee forests. Afr. J. Ecol. 53, 389-397, http://dx.doi.org/10.1111/aje.12203

Hylander, K., Nemomissa, S., 2008. Home garden coffee as a repository of epiphyte biodiversity in Ethiopia. Frontiers Ecol Environ. 6, 524-528, http://dx.doi.org/10.1890/080001

Hylander, K., Nemomissa, S., Delrue, J., Enkosa, W., 2013. Effects of coffee management on deforestation rates and forest integrity. Cons. Biol. 27, 1031-1040, http://dx.doi.org/10.1111/cobi.12079

Jaramillo, J., Muchugu, E., Vega, F.E., Davis, A., Borgemeister, C., Chabi-Olaye, A., 2011. Some like it hot: the influence and implications of climate change on Coffee Berry Borer Hypothenemus hampei and coffee production in East Africa. PLoS ONE 69: e24528, http://dx.doi.org/10.1371/journal.pone.0024528

Jump, A.S., Peñuelas, J., 2006. Genetic effects of chronic habitat fragmentation in a windpollinated tree. Proc. Natl. Acad. Sci. USA 103: 8096-8100, http://dx.doi.org/10.1073/pnas.0510127103 
Jump, A.S., Marchant, R., Peñuelas, J., 2009. Environmental change and the option value of genetic diversity. Trends Plant Sci. 14, 51-58, http://dx.doi.org/10.1016/j.tplants.2008.10.002

Läderach, P., Lundy, M., Jarvis, A., Ramirez, J., Perez Portilla, E., Schepp, K., Etizinger, A., 2010. Predicted impact of climate change on coffee supply chains. In: Filho, W.L. (Ed.). The Economic, Social and Political Elements of Climate Change. Berlin Heidelberg, Germany: Springer, pp 703-723, http://dx.doi.org/10.1007/978-3-642-14776-0_42

Labouisse, J.P., Ballachew, B., Kotecha, S., Bertrand, B., 2008. Current status of coffee Coffea arabica L. genetic resources in Ethiopia: implications for conservation. Genet. Res. Crop Evol. 55, 1079-1093, http://dx.doi.org/10.1007/s10722-008-9361-7

Lin, B.B., 2011. Resilience in agriculture through crop diversification: adaptive management for environmental change. Bioscience 61, 183-193, http://dx.doi.org/10.1525/bio.2011.61.3.4

Muñoz, J.C., Aerts, R., Thijs, K.W., Stevenson, P.R., Muys, B., Sekercioglu, C.H., 2013. Contribution of woody habitat islands to the conservation of birds and their potential ecosystem services in an extensive Colombian rangeland. Agric. Ecosyst. Environ. 173, 13-19, http://dx.doi.org/10.1016/j.agee.2013.04.006

Phalan, B., Balmford, A., Green, R.E., Scharlemann, J.P.W., 2011. Minimising the harm to biodiversity of producing more food globally. Food Policy 36, S62-S71, http://dx.doi.org/10.1016/j.foodpol.2010.11.008

Phalan, B., Bertzky, M., Burchart, S.H.M., Donald, P.F., Scharlemann, J.P.W., Stattersfield, A.J., Balmford, A., 2013. Crop expansion and conservation priorities in tropical countries. PloS ONE, 8, e51759, http://dx.doi.org/10.1371/journal.pone.0051759 
Phalan, B., Green, R.E., Dicks, L.V. et al., 2016. How can higher-yield farming help to spare nature? Science 29, 450-451, http://dx.doi.org/10.1126/science.aad0055

Richerzhagen, C., Virchow, D., 2007. Sustainable utilisation of crop genetic diversity through property rights mechanisms: the case of coffee genetic resources in Ethiopia. Intl. J. Biotech. 9, 60-86, http://dx.doi.org/10.1504/IJBT.2007.012169

Samnegård, U., Hambäck, P.A., Nemomissa, S., Hylander, K., 2014. Dominance of the semiwild honeybee as coffee pollinator across a gradient of shade-tree structure in Ethiopia. J. Trop. Ecol. 30, 401-408, http://dx.doi.org/10.1017/S0266467414000327

Sarrazin, F., Lecomte, J., 2016. Conservation. Evolution in the Anthropocene. Science 351, $922-$ 923, http://dx.doi.org/10.1126/science.aad6759

Schmitt, C.B., Senbeta, F., Denich, M., Preisinger, H., Boehmer, H.J., 2009. Wild coffee management and plant diversity in the montane rainforest of southwestern Ethiopia. Afr. J. Ecol. 48: 78-86, http://dx.doi.org/10.1111/j.1365-2028.2009.01084.x

Schoen, D.J., Brown, A.H.D., 2001. The conservation of wild plant species in seed banks. BioScience 51, 960-966, http://dx.doi.org/10.1641/00063568(2001)051[0960:TCOWPS]2.0.CO;2

Senbeta, F., Denich, M., 2006. Effects of wild coffee management on species diversity in the Afromontane rainforests of Ethiopia. For. Ecol. Manag. 232, 68-74, http://dx.doi.org/10.1016/j.foreco.2006.05.064

Sgrò, C.M., Lowe, A., Hoffmann, A.A., 2011. Building evolutionary resilience for conserving biodiversity under climate change. Evol. Applic. 4: 326-337, http://dx.doi.org/10.1111/j.1752-4571.2010.00157.x 
Silvarolla, M.B., Mazzafera, P., Fazuoli, L.C., 2004. Plant biochemistry: a naturally decaffeinated arabica coffee. Nature 429, 826, http://dx.doi.org/10.1038/429826a

Silvestrini, M., Junqueira, M.G., Favarin, A.C., Guerreiro-Filho, O., Maluf, M.P., Silvarolla, M.B., Colombo, C.A., 2007. Genetic diversity and structure of Ethiopian, Yemen and Brazilian Coffea arabica L. accessions using microsatellite markers. Genet. Res. Crop Evol. 54, 1367-1379, http://dx.doi.org/10.1007/s10722-006-9122-4

Tadesse, G., Zavaleta, E., Shennan, C., 2014a. Coffee landscapes as refugia for native woody biodiversity as forest loss continues in southwest Ethiopia. Biol. Cons. 169, 384-391, http://dx.doi.org/10.1016/j.biocon.2013.11.034

Tadesse, G., Zavaleta, E., Shennan, C., FitzSimmons, M., 2014b. Policy and demographic factors shape deforestation patterns and socio-ecological processes in southwest Ethiopian coffee agroecosystems. Appl. Geogr. 54, 149-159, http://dx.doi.org/10.1016/j.apgeog.2014.08.001

Takahashi, R., Todo, Y., 2014. The impact of a shade coffee certification program on forest conservation using remote sensing and household data. Environ. Impact Assessment Rev. 44, 76-81, http://dx.doi.org/10.1016/j.eiar.2013.10.002

Tesfaye, K., Govers, K., Bekele, E., Borsch, T., 2014. ISSR fingerprinting of Coffea arabica throughout Ethiopia reveals high variability in wild populations and distinguishes them from landraces. Plant Syst. Evol. 300, 881-897, http://dx.doi.org/10.1007/s00606-0130927-2

Tscharntke, T., Clough, Y., Bhagwat, S.A., Buchori, D., Faust, H., Hertel, D., Hölscher, D., Juhrbandt, J., Kessler, M., Perfecto, I., Scherber, C., Schroth, G., Veldkamp, E., Wanger, 
T.C., 2011. Multifunctional shade-tree management in tropical agroforestry landscapes - a review. J. Appl. Ecol. 48, 619-629, http://dx.doi.org/10.1111/j.1365-2664.2010.01939.x

Wiersum, K.F., Gole, T.W., Gatzweiler, F., Volkmann, J., Bognetteau, E., Wirtu, O., 2012. Certification of wild coffee in Ethiopia: experiences and challenges. For. Trees Livelihoods 18, 9-21, http://dx.doi.org/10.1080/14728028.2008.9752614 

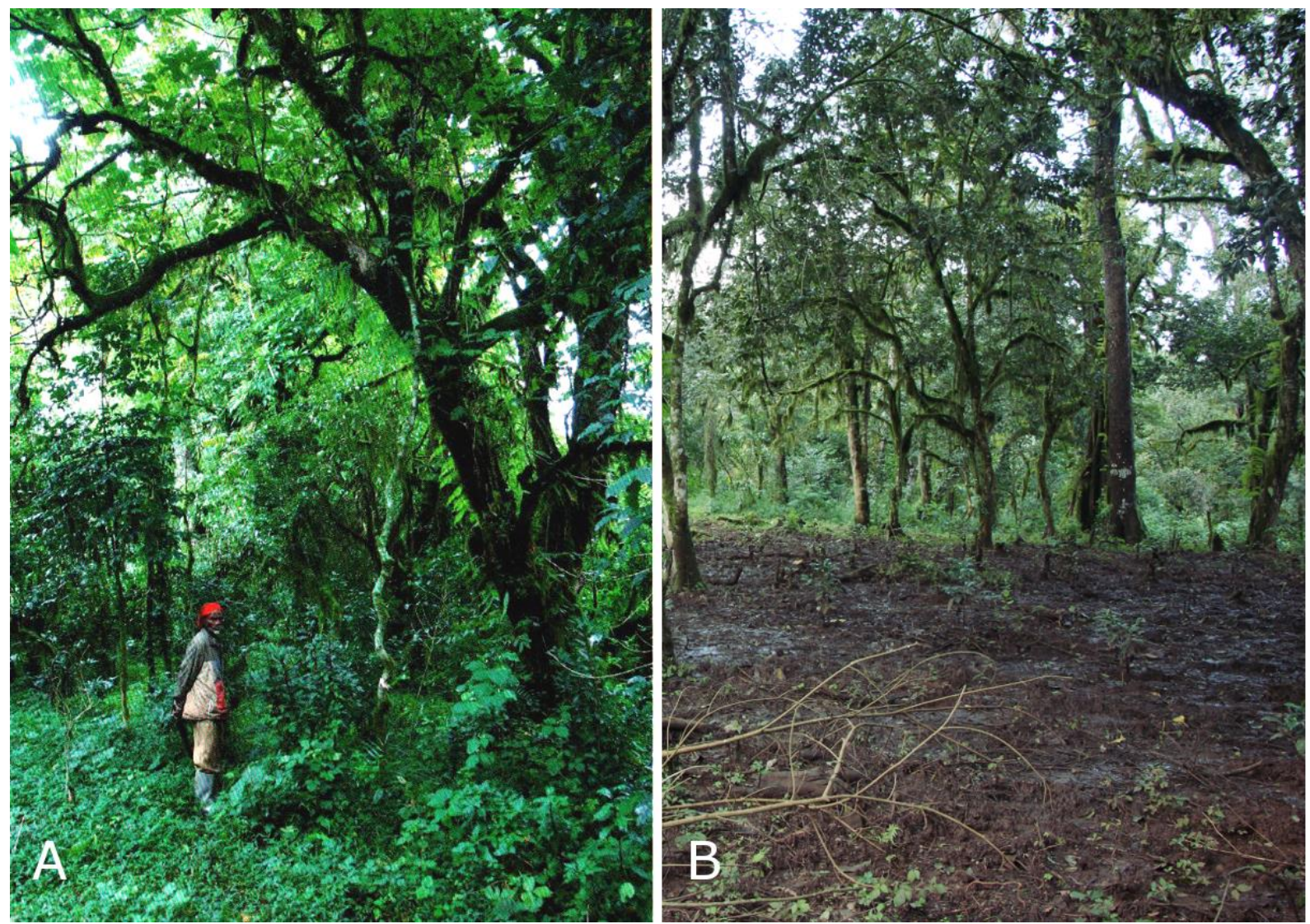

Fig. 1. Coffee forest in SW Ethiopia. This part of the Belete-Gera National Forest Priority

386 Area harbored an undisturbed, wild population of Coffea arabica in 2008 (A). The same stand

387 was re-photographed in 2014 (B). The tallest canopy trees have been cut and the diverse

388 understory vegetation has been replaced by a mixture of transplanted wild $C$. arabica seedlings

389 and acquired C. arabica cultivars. 


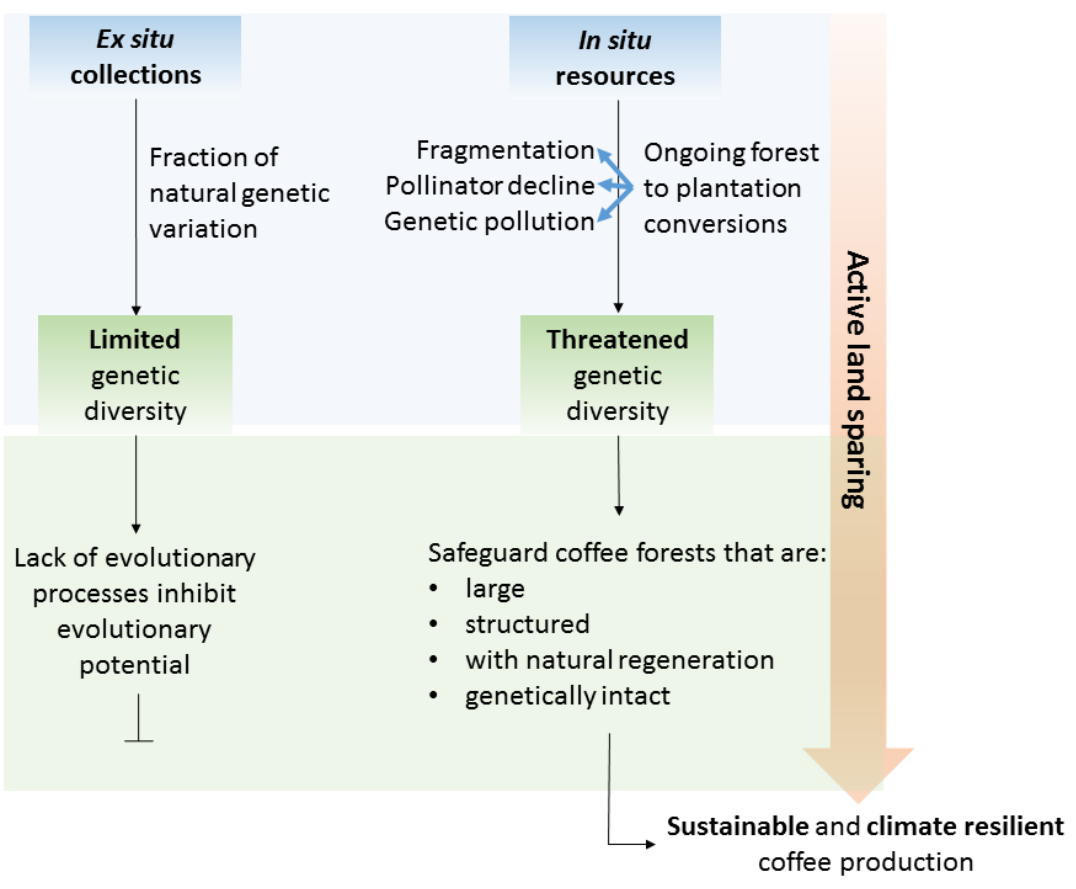

393 Fig. 2. Major threats to ex situ and in situ genetic diversity of Coffea arabica. Strict forest

394 reserves are needed to secure conservation of in situ coffee genetic resources and their

395 evolutionary potential.

396 